\title{
Northern Ireland: Wellbeing as a Vision
}

\begin{abstract}
Northern Ireland introduced its wellbeing framework through the draft Programme for Government in 2016. The approach aimed to create a shared vision for a post-conflict society and assist the powersharing Executive in working together for shared outcomes. Continuing political instability, and the suspension of the Northern Ireland Executive, has limited the implementation of the approach. Despite this, progress has been made in communicating the approach of aligning programme, population and societal outcomes. The wellbeing duty on local government, established in 2014, has been vital in taking forward the approach through Community Plans and all evidence points to a continuation of the wellbeing approach in the revised Programme for Government once the Executive is re-established.
\end{abstract}

Keywords Northern Ireland Assembly • Post-conflict

Good Friday Agreement • Vision • Outcomes · Community planning

We must not be wedded to the old ways of Government and we are committed to a new, better and more innovative approach.

Martin McGuiness MLA (Deputy First Minister, Sinn Fein) speaking in July 2016 (Doran and Woods 2016)

J. Wallace, Wellbeing and Devolution, Wellbeing in Politics and Policy, https://doi.org/10.1007/978-3-030-02230-3_5 
There is a great deal that the governing parties agree on; on having a good health service, economy, and so on. We do have a shared vision and we need to focus on that to implement it. I think people are optimistic.

Emma Little Pengelly, MLA (Junior Minister at the Office of the First Minister and Deputy First Minister, Democratic Unionist Party) speaking in Sept 2016 (Carnegie UK Trust 2017)

\section{INTRODUCTION}

Northern Ireland was the last of the three devolved legislatures in the UK to introduce a wellbeing framework, beginning its journey in 2015 and with a working draft published in 2018. The framework had ambitions to create a conversation that sat above the constitutional debates that create such political vulnerability in Northern Ireland. The suspension of the Northern Ireland Executive in early 2017 is proof that the 'new conversation' has not yet taken root. However, despite the political vacuum, there is still reason to be optimistic.

\section{CONTEXT}

The Acts of Parliament that formally brought the UK and Ireland Parliaments together came into force on 1 January 1801. Ireland was 'partitioned' into north and south in 1921 under the Government of Ireland Act 1920 immediately prior to the Irish war of independence which led to the establishment of the republic in 1922. From 7 June 1921 until 30 March 1972, the devolved legislature for Northern Ireland was the Parliament of Northern Ireland, which always had an Ulster Unionist Party (UUP) majority and always elected a UUP government.

By the late 1960s, tensions between communities in Northern Ireland were rising leading to 'The Troubles', a 30-year period of conflict which led to the deaths of over 3600 people. The Northern Ireland Parliament was suspended on 30 March 1972 and formally abolished in 1973 under the Northern Ireland Constitution Act 1973. For the next 25 years, Northern Ireland was under direct rule from Westminster, managed by a Secretary of State for Northern Ireland.

A lengthy process of talks between the Northern Ireland political parties and the British and Irish Governments resulted in the Good Friday Agreement of April 1998 (Northern Ireland Assembly 1998). The Agreement was endorsed through a referendum held on 22 May 
1998 and subsequently given legal force through the Northern Ireland Act 1998. The Northern Ireland Assembly has full legislative and executive authority for all matters that are the responsibility of the Northern Ireland Government Departments.

The agreement implemented a model of power-sharing government which has brought a form of 'compulsory coalition'. A First Minister and a Deputy First Minister are elected to lead the Executive Committee of Ministers. They must stand for election jointly and to be elected they must have cross-community support by the parallel consent formula, which means that a majority of both the Members who have designated themselves Nationalists and those who have designated themselves Unionists and a majority of the whole Assembly, must vote in favour. In 2012, there were five parties in government and an 'opposition' of only four out of 108 MLAs (Oliver 2013).

Despite the care taken over its design, the Northern Ireland Assembly has not been a stable entity, being suspended five times, two for significant periods of time. It was suspended on 14 October 2002 due to disagreements around weapons decommissioning, the suspension lasting until 8 May 2007. The second lengthy period of suspension is currently ongoing - sparked by the resignation of Martin McGuiness MLA, Deputy First Minister in protest of a scandal involving the Renewable Heat Incentive Scheme in early 2017. A subsequent election did not lead to the establishment of a power-sharing agreement and so negotiations resumed in the autumn of 2017.

At the time of writing (June 2018), the UK Parliament has passed a budget for the financial year of 2017-2018 enacted following the failed talks in February 2018. The overall budget received a boost in 2018-2019 as a result of the confidence and supply arrangement with the UK Government. The 2018-2019 budget identifies the following areas as benefiting from this additional funding: Infrastructure $£ 200 \mathrm{~m}$, Health Transformation $£ 100 \mathrm{~m}$, Health \& Education $£ 80 \mathrm{~m}$, Tackling Severe Deprivation $£ 20 \mathrm{~m}$ and Mental Health $£ 10 \mathrm{~m}$ (Northern Ireland Executive 2018d).

This complicated history is critical to understanding why and how the Northern Ireland Assembly and Executive sought to establish a wellbeing approach. The multi-party Executive had led to a clientelist approach to the development of the programme for government, with each party and individual MLA arguing their own interests, resulting in deeply fragmented government. The aspiration was that a wellbeing framework could assist in longer term political visioning (Table 5.1). 
Table 5.1 Timeline for the development of the Northern Ireland wellbeing framework

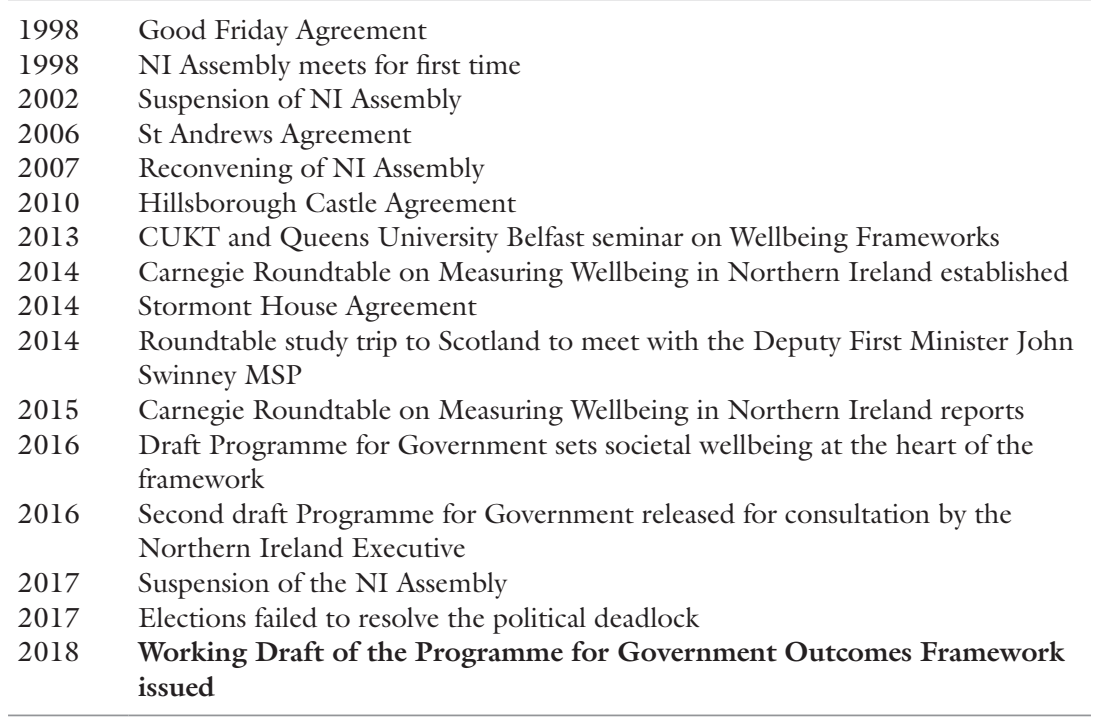

Source Original

\section{Catalysts}

As the brief outline and timeline show, the constitutional settlement between the UK and Northern Ireland has gone through several iterations since devolution in 1998. The 2006 St Andrews Agreement, 2010 Hillsborough Castle Agreement and the 2014 Stormont House Agreement all sought to resolve the issues that were causing political instability. The first set of changes in 2006 brought in a new ministerial code and changed the Good Friday Agreement by setting a process whereby the First Minister and Deputy First Minister are appointed based on the first and second largest party in the Assembly, respectively, and no longer by election of the NI Assembly. In 2010, the Hillsborough Castle Agreement brought in further devolution of policing and justice.

The 2014 Stormont House Agreement set in place institutional changes which, unintentionally, paved the way for the wellbeing 
framework approach. Firstly, they reduced the number of departments from 12 to nine. Secondly and crucially, they agreed that the draft Programme for Government would have to be agreed prior to the appointment of the Executive. While previously, parties and Ministers could argue simply for their 'piece' of the programme (and the budget they felt appropriate to it), they now had to consider the programme in the round, as a full programme for government without special pleading for their own departments.

Spending on public services in Northern Ireland is consistently higher than in England, Scotland and Wales (UK Parliament 2017). But this has not translated into better outcomes for citizens, as one interviewee told me 'money wasn't solving the problems'. As Table 2.2 shows, Northern Ireland scores 'high' on only two out of 11 indicators, scoring poorly (i.e. in the bottom quarter of regions in the UK) on six. Using the NI Research and Statistical Authority 'wheel' of wellbeing indicators, derived from the ONS Measuring National Wellbeing programme and therefore including comparator information with the UK as a whole, Northern Ireland performs worse than the UK as a whole on governance (voting and trust in government), education and skills, personal finances and some aspects of health (NISRA 2017).

While the reasons for poorer outcomes are complex, the system of governance was seen by interviewees as a contributory factor. The power-sharing system meant that previous Programmes for Government had been reduced to 'laundry lists' of project-level targets, requiring government to deliver certain programmes, or spend particular amounts of money. Simon Hamilton MLA (Minister of Finance and Personnel from 2013-2015, Minister of Health, Social Services and Public Safety 20152016 and Minister for the Economy 2016-2017) told me:

We were producing programmes for government which were just long, long, long lists of commitments that were fairly easy to achieve, and we did achieve most of them, but we gained nothing, these was no sense that things were moving in the right direction.

At an operational level, policy development is heavily siloed. On a very pragmatic level, policy-makers in Northern Ireland were aware that budgets would be decreasing in the coming years.

The impetus for moving to a wellbeing approach to government was a recognition that while successive governments were delivering on their 
mandates for that electoral term, outcomes for citizens were not improving. Simon Hamilton MLA went on to comment:

There wasn't a eureka moment, a moment the penny collectively dropped, but below the surface there had been a growing sense of dissatisfaction. There was a sense that we hadn't been making the most of devolution, that the survival of devolution itself wasn't enough... there was a feeling that devolution wasn't improving people's lives in the ways that it was supposed to.

While internally to the government there may have been clarity over the nature of the problem, the identification of a wellbeing approach as a potential solution came from non-governmental organisations, through two initiatives that began as separate entities but came quickly to similar conclusions.

The first was the Carnegie Roundtable on Measuring Wellbeing in Northern Ireland, a partnership between the Carnegie UK Trust and Queens University Belfast established in 2013. The 18 members comprised civil servants and individuals from business, the third sector, youth, academia and local government. The group's deliberations followed the definitions of the Stiglitz-Sen-Fitoussi commission (2009) and from the outset the Roundtable identified the need to encourage a new narrative or vision drawing on the language of wellbeing:

In order to move forward, we need an idea of where we are going and one that resonates with citizens. Wellbeing provides an easily understood concept which can form the basis of a new approach to the relationship between citizens and government, focusing on assets and shared responsibilities between citizens, communities, government and the private sector. The concept of wellbeing can be used to link the everyday experiences and priorities of people with the sometimes remote and often opaque world of policymaking and politics. (Carnegie UK Trust 2015, p. 5)

Democratic accountability and public trust were core to the aims of the wellbeing framework, as conceived by the Roundtable. They concluded that the time was right to develop a 'wellbeing framework' to guide and support the work of all public services in Northern Ireland and identified seven steps in taking forward this agenda:

Step 1: Set wellbeing as our collective goal

Step 2: Engage the public

Step 3: Establish new ways of working 
Step 4: Align tiers of government

Step 5: Communicate social progress

Step 6: Improve accountability

Step 7: Support the Wellbeing Framework (Carnegie UK Trust 2015).

The second initiative was led by the National Children's Bureau NI and focused on advocating for outcomes-based accountability (OBA). The origins of this initiative followed the post New Performance Management thinking, with Celine McStravick ${ }^{1}$ noting the frustration that despite all the funding being invested in Northern Ireland, outcomes for children were not improving. The NCB NI were influenced heavily by Mark Friedman's methodology, an approach which aims to improve programme and population outcomes (Friedman 2005). Here outcomes are defined as 'a population condition of well-being for children, adults, families and communities, stated in plain language' (p. 19).

These two initiatives shared the aim of having a much clearer idea of where NI is heading, and what kind of society it aspires to be. But there are differences too. The Carnegie Roundtable approach was based on the desire to rebalance decision-making away from economic dominance and towards social and economic outcomes. Friedman's methodology is agnostic on this point. And while the definition of outcomes is the same, the scope differs. Friedman's approach does not seek to agree outcomes across all domains of wellbeing - it may for example relate to a good start in life for children, or a clean environment. A further issue is that looking at OBA at programme level inevitably means a focus on particular groups in society. It does not tell you how society as a whole is progressing, or if there are trade-offs between different groups when making decisions. So we can see that these initiatives are operating at different strategic levels in public services.

The two initiatives have been mutually supportive by creating a supportive political and civil service environment for outcomes to be discussed. Both initiatives held large events in 2016 with clear political support. For example, the NCB event included addresses by the First Minister Arlene Foster and the Deputy First Minister Martin McGuiness and had an audience of almost 500 (public policy conferences in devolved administrations rarely involve over 100 people).

\footnotetext{
${ }^{1}$ Celine McStravick is Director of NCB in Northern Ireland and a leader in the campaign to introduce Outcomes Based Accountability to Northern Ireland.
} 
This positive momentum was short-lived, however, as Celine McStravick told me: 'We felt we were starting to see real movement in government and we were looking forward to collaborative delivery plans coming out... but that didn't happen. Within eight weeks we had no Executive and within 12 weeks our Deputy First Minister had passed away'.

\section{COMPOnents}

There have now been three iterations of this Programme for Government, the first and second both issued in 2016 and the third, current 'working draft' which is still subject to political agreement. It is this working draft that I refer to in this analysis (Northern Ireland Executive 2018a). It contains:

- A purpose statement: 'Improving wellbeing for all—by tackling disadvantage and driving economic growth'

- 12 outcomes:

1. We prosper through a strong, competitive, regionally balanced economy

2. We live and work sustainably - protecting the environment

3. We have a more equal society

4. We enjoy long, healthy, active lives

5 . We are an innovative, creative society, where people can fulfil their potential

6. We have more people working in better jobs

7. We have a safe community where we respect the law, and each other

8. We care for others and we help those in need

9. We are a shared, welcoming and confident society that respects diversity

10. We have created a place where people want to live and work, to visit and invest

11. We connect people and opportunities through our infrastructure

12. We give our children and young people the best start in life

- 49 indicators, including four indexes: the private sector NI Composite Economic Index, a Respect Index, a Nation Brands Index, A Better Jobs Index (see Table 5.2). 
Table 5.2 Wellbeing indicators for Northern Ireland

\begin{tabular}{|c|c|c|}
\hline Material conditions & Quality of life & Environment \\
\hline $\begin{array}{l}\text { Private sector NI Composite } \\
\text { Economic Index (index, } \\
\text { objective) }\end{array}$ & $\begin{array}{l}\text { Confidence of older people } \\
(\%, \text { subjective })\end{array}$ & $\begin{array}{l}\text { Waste recycled (number, } \\
\text { objective) }\end{array}$ \\
\hline External sales ( $£$, objective) & $\begin{array}{l}\text { Inequality in healthy life } \\
\text { expectancy ( } \%, \text { objective) }\end{array}$ & $\begin{array}{l}\text { Greenhouse gas emissions } \\
\text { (number, objective) }\end{array}$ \\
\hline $\begin{array}{l}\text { Business innovation } \\
(\%, \text { objective })\end{array}$ & $\begin{array}{l}\text { Attainment gap } \\
(\%, \text { objective })\end{array}$ & Active travel (\%, objective) \\
\hline $\begin{array}{l}\text { Employment rate by council } \\
(\%, \text { objective })\end{array}$ & $\begin{array}{l}\text { Healthy life expectancy } \\
(\%, \text { objective })\end{array}$ & $\begin{array}{l}\text { Air quality (number, } \\
\text { objective) }\end{array}$ \\
\hline $\begin{array}{l}\text { Energy security } \\
(\%, \text { objective })\end{array}$ & $\begin{array}{l}\text { Preventable mortality } \\
(\%, \text { objective })\end{array}$ & $\begin{array}{l}\text { Marine quality (number, } \\
\text { objective) }\end{array}$ \\
\hline $\begin{array}{l}\text { Income poverty } \\
(\%, \text { objective })\end{array}$ & $\begin{array}{l}\text { Mental wellbeing } \\
(\%, \text { subjective })\end{array}$ & Biodiversity (\%, objective) \\
\hline $\begin{array}{l}\text { Employment inequality } \\
(\%, \text { objective })\end{array}$ & $\begin{array}{l}\text { Quality of health and social } \\
\text { care (in development) }\end{array}$ & Water quality $(\%$, objective $)$ \\
\hline $\begin{array}{l}\text { Economic inactivity } \\
(\%, \text { objective })\end{array}$ & $\begin{array}{l}\text { Educational attainment } \\
(\%, \text { objective })\end{array}$ & \\
\hline $\begin{array}{l}\text { A Better Jobs Index } \\
\text { (in development) }\end{array}$ & $\begin{array}{l}\text { Access to superfast broad- } \\
\text { band }(\%, \text { objective })\end{array}$ & \\
\hline $\begin{array}{l}\text { Under-employment } \\
(\%, \text { objective })\end{array}$ & $\begin{array}{l}\text { Engagement in arts/culture } \\
(\%, \text { objective })\end{array}$ & \\
\hline $\begin{array}{l}\text { Graduate destinations } \\
(\%, \text { objective })\end{array}$ & $\begin{array}{l}\text { Perception of respect for } \\
\text { cultural identity } \\
(\%, \text { subjective })\end{array}$ & \\
\hline $\begin{array}{l}\text { Total spend by external } \\
\text { visitors }(£ \text {, objective })\end{array}$ & $\begin{array}{l}\text { Respect Index (in } \\
\text { development) }\end{array}$ & \\
\hline $\begin{array}{l}\text { Reputation (Index, } \\
\text { objective) }\end{array}$ & Crime rate ( $\%$, objective $)$ & \\
\hline $\begin{array}{l}\text { Average journey time on } \\
\text { key economic corridors (in } \\
\text { development) }\end{array}$ & $\begin{array}{l}\text { Length of criminal cases } \\
\text { (time, administrative) }\end{array}$ & \\
\hline $\begin{array}{l}\text { Seasonally adjusted employ- } \\
\text { ment rate }(\% \text {, objective })\end{array}$ & $\begin{array}{l}\text { Reoffending rate } \\
(\%, \text { objective })\end{array}$ & \\
\hline \multirow[t]{8}{*}{$\begin{array}{l}\text { Housing supply } \\
(\%, \text { objective })\end{array}$} & $\begin{array}{l}\text { Control over social care } \\
(\%, \text { objective })\end{array}$ & \\
\hline & Life satisfaction of people & \\
\hline & with disabilities & \\
\hline & $(\%$, subjective $)$ & \\
\hline & Households in housing & \\
\hline & $\begin{array}{l}\text { stress }(\%, \text { objective }) \\
\text { Perception of openness to }\end{array}$ & \\
\hline & Catholics and Protestants & \\
\hline & $(\%$, subjective $)$ & \\
\hline
\end{tabular}


Table 5.2 (continued)

\begin{tabular}{lll}
\hline Material conditions & Quality of life & Environment \\
\hline & Online use of public services & \\
& (in development) & \\
& Low birth weight & \\
& $(\%$, objective) & \\
& Quality of schools & \\
& $(\%$, objective) & \\
& Destination of care leavers & \\
& (\%, objective) & \\
& Child development & \\
& (in development) & \\
& Confidence of the popula- & \\
& tion (\%, subjective) & \\
& Skills level of the population & \\
& & \\
Total: 16 & Total: 26 & Total: 7 \\
14 objective, 2 in & 6 subjective, 1 adminis- & 7 objective \\
development & trative, 15 objective, 4 in & \\
& development & \\
\hline
\end{tabular}

Source Northern Ireland Executive (2018a)

\section{Contributions}

\section{A New Narrative on Wellbeing}

No more silo working but working across boundaries, organisations, groups and the community for the common good.

Martin McGuiness MLA speaking in July 2016

(Doran and Woods 2016)

The fragility of the political environment in Northern Ireland affects each area of implementation of a wellbeing framework. As the OECD review concluded 'the divisions in Northern Ireland are an endemic factor which affects most areas of government and public administration' (2016, p. 84). Those involved in advocating for wellbeing frameworks were conscious of this and argued that the challenges of the 21 st century required $a$ new conversation for new times. As Simon Hamilton MLA told me:

We have political parties in government together who don't share the same vision... even though we have a consensus model and try to bring everyone together and govern together, everything is fractured. So it made 
sense to stop, shape a vision of what we're trying to work towards and then set out to achieve it.

In emerging from conflict, Northern Ireland has an urgent need for new political narratives:

In a post-conflict society, much is at stake in the design and delivery of policy. There are risks for all of us when public confidence falls away from systems of governance and a disconnect between politics and the lives of citizens is allowed to replace an enlivened sense of ownership, accountability and engagement.

Every negative perception of governance - expressed as concerns about security, welfare, social exclusion, health or budgeting - carries the weight of a deeper possibility: a crisis in the implicit social contract or understanding between government and citizen, with all of the risks that entails for a society journeying out of enmity. (Doran et al. 2015, p. 31)

The opportunity provided by a wellbeing framework is to create a common language that sits above the political decisions and constitutional struggles without suggesting that these do not exist. In a post-conflict society, it is a tight-rope walk.

The conversation around the wellbeing framework was the first real attempt by the politicians in Northern Ireland to have a discussion with each other, stakeholders and eventually the public, that centred on values and principles, rather than pragmatic politics. Gray and Birrell argued 'there has been a notable absence of reference in policy documents to a conceptual and values base for policy decisions' (2016, p. 164).

Political support for the approach was carefully cultivated with the DUP and Sinn Fein represented at the Carnegie Roundtable. Early support from Simon Hamilton MLA (Democratic Unionist Party) and the Chair of the Finance Committee (Daithi MacKay MLA, Sinn Fein) was backed up by 2016 with clear support from the First Minister and Deputy First Minster:

One of the successes was listening to the politicians at the same time as we were talking to the senior civil service and taking cognisance of the advice from within the system who were very respectful of the politics. I think that combination's almost unique. (Aideen McGinley, ${ }^{2}$ interview)

${ }^{2}$ Aideen McGinley was Co-Chair, of the Carnegie Roundtable on Measuring Wellbeing in Northern Ireland, she was formerly a permanent secretary in the Northern Ireland Executive and Chief Executive of Fermanagh District Council. 
The opportunity to speak of aspirations for Northern Ireland without recourse to the constitutional issues provided a glimmer of hope in how a new politics could be created.

Not all parties were supportive of the new Programme for Government. Smaller parties such as UUP, did not support the draft Programme for Government in 2016 and refused to take part in the newly formed power-sharing executive. Their criticism was of the lack of detail in the draft Programme for Government on the deliverables, calling the draft framework of outcomes 'motherhood and apple pie' (BBC 2016).

The sudden stoppage of the Northern Ireland Assembly has held the wellbeing framework in suspended animation-neither fully implemented nor fully dormant. There is however a clear commitment from the civil service, local government and civil society to the wellbeing framework contained within the draft Programme for Government.

\section{Horizontal Integration}

Reform of the Northern Ireland Civil Service was underway prior to the wellbeing framework but is part of the same set of reforms. Departmental restructuring was announced in March 2015 with a reduction of departments from 12 to nine, to provide greater coherence in department responsibilities and a reduction of duplication of effort.

The OECD's first subnational Public Governance Review was commissioned in Northern Ireland by Simon Hamilton while he was Minister in the Department of Finance in 2014. The review found that the lack of horizontal integration across government departments was a key cause of inefficiency and duplication. It found that the Executive was not functioning as an effective centre of government, instead using its time and resources to resolve political disagreements. It concluded that in practice the Executive was not effectively exercising its role in strategy-setting, playing only a limited role in whole-of-government oversight and coordination and failing to exercise collective responsibility for decision-making (OECD 2016).

Speaking soon after the report launch, the author Adam Ostry underlined current fiscal constraints and the specific challenges of coalition government in Northern Ireland, with the subsequent 
demand for 'leadership and fearlessness' from a non-partisan civil service equipped to deliver evidence-based policy advice (Doran and Woods 2016).

Ministers therefore used the draft Programme for Government to give strong messages to civil servants that they had permission to work across departmental boundaries. Interviewees report a significant shift in willingness of civil servants to discuss policy interventions that they would not previously have seen as their responsibility-for example the Department of Education taking an active role in services for pre-school children and engaging proactively with health colleagues, or diabetes strategies being implemented through education services.

The NI Civil Service have been working hard to address the issue of taking forward the approach without a government, as one interviewee summarised: 'You can't have a programme for government without a government [nonetheless] there was a clear direction of travel, and political support for that direction of travel. There is also continuing support from very many of the key vehicles that the government would do business with in the community and private sector.'

There have been examples of alignment between the draft Programme for Government and departmental strategy documents such as the Health and Social Care Workforce Strategy 2026, which states alignment with the PFG and includes actions on multidisciplinary and inter-professional working and training (Northern Ireland Executive 2018c). This strategy benefited from an allocation from the $£ 1$ billion boost to the NI finances from the Confidence and Supply arrangement with the UK Government following the 2016 UK General Election (Box 5.1).

\section{Box 5.1: Case Study: Digital Transformation Strategy}

The Programme for Government (PfG) includes a commitment to increasing use of online channels (Northern Ireland Executive $2018 \mathrm{~b}$ ). As this is an area that cuts across departments the Digital Transformation Strategy has been developed to align with other key Government Strategies including the eHealth and Care Strategy for Northern Ireland and the forthcoming Industrial Strategy. The Digital Leaders Forum and the niDirect User forum are being refined and reinvigorated to improve support for, and shaping of, the identified programme of work and ensure that all departmental strategies and action plans are aligned with the digital service Strategy. 
But the strategy goes further than bringing others together to support the achievement of the digital indicator, it also identifies that digital public services have a real and meaningful impact on the daily lives of our citizens which helps achieve the outcomes agreed in the PfG. The strategy sets out to promote digital thinking and collaboration within policy development and planning to place digital services at the forefront of supporting PfG outcome-based delivery. While it is too early to identify specific policy outcomes from this intention, there is a clear 'golden thread' in the advocacy of the wellbeing framework that is contributing to changing behaviours.

In mid-2018 the Executive Office published an Outcomes Delivery Plan 2018-2019 which takes as its starting point the 12 outcomes set in the draft Programme for Government and provides 'direction and clarity' for those working within the system (Northern Ireland Executive 2018e, p. 1). The document identifies outcome owners for each of the twelve outcomes, within the civil services, and each outcome chapter is co-authored by civil servants from different but relevant departments.

The NI Audit Office soon after published a good practice guide for public bodies on performance management, outlining its expectations on the connection between the Programme for Government outcomes and indicators and those developed by public bodies and reported through their Delivery Plans (see Box 5.2).

\section{Box 5.2: Northern Ireland's tiered approach to accountability} for outcomes

- Programme outcomes: relating to the users of the service (e.g. improved personal wellbeing).

- Population outcomes: relating to the whole population but for a specific outcome (e.g. living healthier lives).

- Societal outcomes: relating to the whole population, for the set of outcomes that reflects societies' view of what comprises wellbeing. 
The guidance separates out the accountability for performance management from direct accountability for the Programme for Government outcomes (Nothern Ireland Audit Office 2018). As they note, there has been significant confusion over accountability and they endorse the view of the Building Change Trust that:

No single programme of intervention can be held solely accountable for the achievement of any PFG outcome. Rather it is the sum of the contributions of agencies, programmes and services that move us towards the realisation of outcomes for the population. And so those who plan or provide interventions are answerable for the extent to which their activities deliver the contributions promised (performance accountability) but not for the delivery of PfG outcomes (population accountability). (Inspiring Impact 2017, p. 23)

This guide, and the above description, has significance for wellbeing frameworks in the rest of the UK and further afield, where the relationship between performance management and societal wellbeing has not been as clearly articulated. This is an issue I will return to in Chapters 6 and 7 .

\section{Vertical Integration}

Community leadership and local government play an important part in the outcomes approach story. Local government in Northern Ireland is responsible for community planning, waste and recycling services, leisure and community services, building control and local economic and cultural development. Unlike Wales and Scotland, they are not responsible for education which is managed by one body, the Education Authority (2018) or housing, managed by the Northern Ireland Housing Executive.

The Local Government Act (Northern Ireland) 2014, gave the eleven newly created local authorities (down from 26) the responsibility for leading community planning processes for their respective districts. In doing so they must identify:

a. long-term objectives for improving the social, economic and environmental well-being of the district and

b. long-term objectives in relation to the district for contributing to the achievement of sustainable development in Northern Ireland. 
The purpose of the reform of local government was to create efficiency savings (to be reinvested into services), to strengthen the coherence of local public services and to provide local government with the key role in relation to Community Planning (OECD 2016). Given this legislation places duties on sustainable development and societal wellbeing, it is notable how rarely it is used to contextualise the work on OBA, again suggesting the initiatives operate at different levels.

The resultant Community Plans extend beyond the local government electoral cycle (next elections in 2019) with six plans looking forward as far as 2030, and four to 2032. The Plans act as local wellbeing frameworks in which local authorities and their partners as Community Planning Partnerships must take account of wellbeing at a local and NI level.

As the NI Local Government Association notes in its response to the draft Programme for Government:

Councils are working with their community planning partnerships to develop local sets of outcomes and indicators, and it is vital that all participants - central and local - are facilitated by district councils to ensure that each local area is involved in informing and in contributing to achieving the agreed Northern Ireland outcomes, the necessary action plans, performance framework and local priorities which will form part of the overall 'jigsaw' of strategy for the foreseeable future. (NI Local Government Association (NILGA) 2016, p. 3)

Local councils see the Programme for Government as part of 'a family of plans' but alignment is not straightforward. It is complicated by the different timescales between the Executive and local council. Community plans tend to be long term, up to 2030, whereas the Executive's Programme for Government would normally encompass a five-year term. Nevertheless, Aideen McGinley who reviewed each one for the Carnegie UK Trust Chair of the Embedding Wellbeing in Northern Ireland programme, told me 'every one of the local government community plans worked towards the draft Programme for Government in terms of what their outcomes are and they are continuing to do that' (Box 5.3). 
Box 5.3: Case study: Armagh City, Banbridge and Craigavon Borough Community Plan 2017-2030

ABC Borough adopted an outcomes-based approach for its community plan and used processes and approaches that align with the wider wellbeing approach. The Borough used an open and consultative approach to developing its Community Plan, in particular making use of digital resources such as their online consultation hub https:// armaghbanbridgecraigavon.citizenspace.com/ and holding thematic workshops in which 245 people expressed their views and opinions on where their priorities should be focused.

The plan identifies three cross-cutting themes (connectivity, equality and sustainability) and nine outcomes (confident community, healthy community, welcoming community; enterprising economy, skilled economy, tourism economy; creative place, enhanced place, revitalised place). While the language differs from the Programme for Government, the approach is aligned and the community plan document includes an annex that shows how the two lists of outcomes relate to one another. There is also some alignment with indicators, particularly around the health and economy outcomes and the Borough has also selected a number of additional indicators to reflect its own needs and priorities, such as the number of highquality parks/green spaces and the percentage of people who feel that the town centre is a safe and welcoming place.

For implementation, outcomes have a designated Thematic Action Planning Team which is charged with developing a two-year action plan, focusing on the collaborative actions. In some cases, these teams are responsible for more than one outcome. The community plan conforms to the differentiation made between population outcomes and performance management, making it clear that the indicators are set for population level with the Action Plans expected to stipulate separate performance management indicators.

In a further innovation, the Borough is proposing to establish a community panel with membership from the community and voluntary sector to assist in the governance structure for community planning. There is no upper limit for the panel. The group will have a specific remit for advising on engagement and communication with communities. 
To aid in the development of indicators to map progress, and to ensure alignment to the Northern Ireland indicators, each local council was offered the services of a NISRA statistician (though this did have to be paid for). The impact can be seen in a number of Community Plans which successfully balance the connection with the PfG indicators and the indicators that are available and relevant locally (e.g. Lisburn and Castlereagh Council). This was a radical step change for the agency which had not previously worked directly with local government. In a further show of support for the Friedman approach, NISRA statisticians have all been trained in outcomes-based approach (OBA) techniques.

Aside from this technical offering, there are concerns that support for implementation has been limited to statutory guidance for the operation of community planning from the Northern Ireland Executive, and the services of Community Places, an independent organisation which provides advice and guidance on outcomes-based community planning and the structure and content of Community Plans. The Northern Ireland Local Government Association (NILGA) has called for more budgetary certainty to support longer term council investment decisions designed to assist in the delivery of the Programme for Government and community planning.

\section{Prevention}

Narratives on prevention as a part of the wellbeing approach are not well established in Northern Ireland. As with the other jurisdiction, there is a strong conflation of prevention as an early intervention for children. For example, the Early Intervention Transformation Programme is a $£ 25$ million investment that aims to improve outcomes for children and young people across Northern Ireland by embedding early intervention approaches. It is funded jointly by five government departments and the Atlantic Philanthropies, itself evidence of a shift towards horizontal integration. It was established in 2015 , prior to the wellbeing framework but is now seen by stakeholders as a major contribution to the outcome 'we give our children and young people the best start in life' with the lead indicator being 'percentage of children who are at the appropriate stage of development in their immediate school year'. The projects funded include ante-natal education and care, and family and employability support to young parents serving custodial services (Social Change Initiative 2017). 
The health sector has innovated on interventions that allow people to receive health and social care at home. The Programme for Government includes a specific indicator on this as an outcome on quality of life. The NI-wide Acute Care at Home programme will make sure that patients have, within their own home environment, the same access to specialist tests as hospital inpatients and receive consultant led assessment and treatment. Southern Health and Social Care Trust, which has been piloting the programme since 2014 has reported a $22 \%$ reduction in acute bed days from nursing homes amounting to a $64 \%$ reduction in cost by providing care in the community setting (Tonner and Farrell 2017). Roll-out is expected to be completed by 2020. A recent publication on community development for health is further evidence of a broadening of the concept of prevention.

\section{Participation}

The Northern Ireland Executive was conscious that moving to a vision of wellbeing and improved outcomes for citizens would require involvement from actors outside of government. Previous Programmes for Government had attracted very little response when open for consultation. However, the new outcomes-based draft Programme for Government attracted five times more responses than the previous version when it was released for consultation in 2016 (Menzies 2017).

Northern Ireland has a less than straight forward history on citizen engagement. Immediately post-devolution, a Civic Forum was established as part of the Good Friday Agreement but the Forum was closed during the first suspension of the Assembly. In 2016, the First Minister the Rt. Hon. Arlene Foster and deputy First Minister, Martin McGuinness announced the creation of a new six-person panel from civic society, as promised in the Fresh Start Agreement. The panel consists of members who hold prominent roles in community and voluntary sector organisations. It is currently suspended due to the suspension of the Assembly.

The OECD review on Public Governance concluded that too much engagement remains procedural (OECD 2016). The draft Programme for Government did not include democratic engagement as an outcome. This led to some losing trust in the process of establishing the outcomes, with concerns raised that the Programme for Government outcomes were pre-determined (Carnegie UK Trust 2017). There has also been 
very little information on how the measurement of social progress will be communicated to stakeholders and citizens.

Outside of government, the Building Change Trust has been active in supporting greater participatory democracy. Their Civic Activism programme is testing out a range of participatory tools to explore their applicability to Northern Ireland. They have also recently announced that they will fund a Citizens' Assembly, the first for Northern Ireland, and they convene and fund the Northern Ireland Open Government Network.

Participatory budgeting is similarly at an early stage in Northern Ireland, again with the impetus coming from the independent funding sector rather than government itself. This initiative is led by the Big Lottery Fund and seeks to create an environment that would be able and willing to experiment with participatory budgeting. These two initiatives are very much at the advocacy change stage of the policy process.

At a local level, there have been much more compelling stories of engagement, with the Belfast Agenda (their Community Plan) developed in consultation with 200 organisations and 2000 individuals through a series of consultation and engagement events (Belfast City Council 2017).

\section{Budgeting}

The budget process has been heavily affected by the political instability. With no Minister to approve the budget, it was sent to the UK Minister to approve for 2018/2019. The detailed governance arrangements for the NI Executive are particularly onerous and difficult to implement flexibly (Northern Ireland Audit Office 2018).

The absence of a government does not provide greater flexibility to the civil servants. Their limited power over decisions was reinforced in mid-2018 by a Belfast High Court judgement which blocked a decision by a senior civil servant to approve a waste incinerator plant (Belfast Telegraph 2018).

There are examples of pooling budgets to allow for horizontal integration, such as the $£ 25 \mathrm{~m}$ Early Intervention Transformation Programme and the $£ 100 \mathrm{~m}$ Health Transformation programme, but the strict rules on budget allocation means that greater flexibility in funding for prevention or joined-up working is likely to be difficult to achieve (Northern Ireland Audit Office 2018). 


\section{Conclusions}

The politicians in Northern Ireland took a bold step in 2016 by shifting their whole programme for government to become a wellbeing framework. This willingness to try a different approach, in a complex and tense political environment, should be applauded.

The political instability has left the project incomplete. Previous analysis has shown the importance of leadership in moving forward culture change, but in Northern Ireland, the lack of political leadership is also compounded by significant change within the civil service with many of the key senior civil servants involved in initiating the new approach having moved on or retired. This analysis was completed while Stormont was still suspended in 2018. However, all evidence points to a continuation of the wellbeing approach in any revised Programme for Government.

In that vacuum, local government and Community Planning Partnerships have continued to develop their approaches further, with a legislative base that refers to sustainable development and using the draft Programme for Government for guidance.

\section{REFERENCES}

BBC. (2016). NI Assembly: UUP Will Go into into Opposition at Stormont [Online]. Available at http://www.bbc.co.uk/news/uk-northern-ireland-36277973. Accessed Mar 2018.

Belfast City Council. (2017). Belfast Agenda Public Consultation Feedback Report. Belfast: Belfast City Council.

Belfast Telegraph. (2018). Court Ruling on Civil Servants Could Have Major Impact on Northern Ireland Decision-Making [Online]. Available at https://www. belfasttelegraph.co.uk/news/northern-ireland/court-ruling-on-civil-servantscould-have-major-impact-on-northern-ireland-decisionmaking-36906250.html. Accessed June 2018.

Carnegie UK Trust. (2015). Towards a Wellbeing Framework: Findings from the Roundtable on Measuring Wellbeing in Northern Ireland. Dunfermline: Carnegie UK Trust.

Carnegie UK Trust. (2017). Towards a Wellbeing Framework: From Outcomes to Actions (Conference Report). Dunfermline: Carnegie UK Trust.

Doran, P., Wallace, J., \& Woods, J. (2015). Towards a Wellbeing Framework: Background Report Prepared for the Rountable on Measuring Wellbeing in Northern Ireland. Dunfermline: Carnegie UK Trust.

Doran, P., \& Woods, J. (2016). Report of the Carnegie Roundtable on Measuring Wellbeing 7 July 2016. Dunfermline: Carnegie UK Trust. 
Education Authority. (2018). Education Authority/About Us [Online]. Available at http://www.eani.org.uk/about-us/. Accessed 2018.

Friedman, M. (2005). Trying Hard Is Not Good Enough: How to Produce Measurable Improvements for Customers and Communities. Santa Fe: FPSI Publishing.

Gray, A. M., \& Birrell, D. (2016). Social Policy in Northern Ireland. In P. Alcock, T. Haux, M. May, \& S. Wright (Eds.), The Student's Companion to Social Policy (pp. 160-166). Chichester: Wiley Blackwell.

Inspiring Impact. (2017). Navigating Change: An Action Learning Project About Funding Outcomes. Belfast: Building Change Trust.

Menzies, R. (2017). From a Shared Vision to Inclusive Implementation: Innovative Approaches to Developing Government Frameworks on Wellbeing. Dunfermline: Carnegie UK Trust.

NI Local Government Association (NILGA). (2016). NILGA Response to the Draft Programme for Government Consultation. Belfast: NILGA.

NISRA. (2017). UK National Wellbeing Measures: Northern Ireland Data. Belfast: NISRA.

Northern Ireland Assembly. (1998). The Agreement Reached In the Multiparty Negotiations [Online]. Available at http://archive.niassembly.gov.uk/io/ agreement.htm. Accessed Jan 2018.

Northern Ireland Executive. (2018a). Working Draft Programme for Government. Belfast: Northern Ireland Executive.

Northern Ireland Executive. (2018b). Making Lives Better: A Strategy for Digital Transformation of Public Services 2017-2021. Belfast: NI Executive.

Northern Ireland Executive. (2018c). Health and Social Care Workforce Strategy 2026. Belfast: NI Executive.

Northern Ireland Executive. (2018d). 2018-19 Northern Ireland Finances. Belfast: NI Executive.

Northern Ireland Executive. (2018e). Outcomes Delivery Plan 2018-19. Belfast: Northern Ireland Executive Office.

Northern Ireland Audit Office. (2018). Performance Management for Outcomes. Belfast: Northern Ireland Audit Office.

OECD. (2016). Public Governance Review of Northern Ireland. Paris: OECD.

Oliver, Q. (2013). The Enabling State in Northern Ireland. Dunfermline: Carnegie UK Trust.

Social Change Initiative. (2017). The Journey so Far Towards Early Intervention in Northern Ireland. Dublin: The Social Change Initiative.

Stiglitz, J., Sen, A., \& Fitoussi, J.-P. (2009). Report by the Commission on the Measurement of Economic Performance and Social Progress [Online]. Available at www.stiglitz-sen-fitoussi.fr. 
Tonner, R., \& Farrell, E. (2017). Impact of an Acute Care at Home Service on Acute Services [Online]. Available at http://www.southerntrust.hscni.net/pdf/ Item_5_SHSCT_Acute_Care_at_Home_ICIC_2017.pdf. Accessed June 2018.

UK Parliament. (2017). Research Briefing: Public Spending by Country and Region [Online]. Available at http://researchbriefings.parliament.uk/ResearchBriefing/ Summary/SN04033. Accessed 2018.

Open Access This chapter is licensed under the terms of the Creative Commons Attribution 4.0 International License (http://creativecommons.org/licenses/ by $/ 4.0 /$ ), which permits use, sharing, adaptation, distribution and reproduction in any medium or format, as long as you give appropriate credit to the original author(s) and the source, provide a link to the Creative Commons license and indicate if changes were made.

The images or other third party material in this chapter are included in the chapter's Creative Commons license, unless indicated otherwise in a credit line to the material. If material is not included in the chapter's Creative Commons license and your intended use is not permitted by statutory regulation or exceeds the permitted use, you will need to obtain permission directly from the copyright holder.

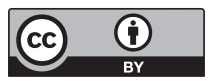

